Research Article

CrossMark

\& cickfor updates

\title{
Performance of Sponge Gourd Cultivars under Organic and Inorganic Fertilizer Regimes
}

\author{
Peer Sikandar Shah ${ }^{1}$, Ghulam Nabi ${ }^{1}$, Maqsood Khan ${ }^{* 1,2}$, Saddam Hussain ${ }^{1}$ and Jawad Ali Jan ${ }^{1}$
}

${ }^{1}$ The University of Agriculture Peshawar, Khyber Pakhtunkbwa, Pakistan; ${ }^{2}$ Northwest A \& F University, Yangling-China

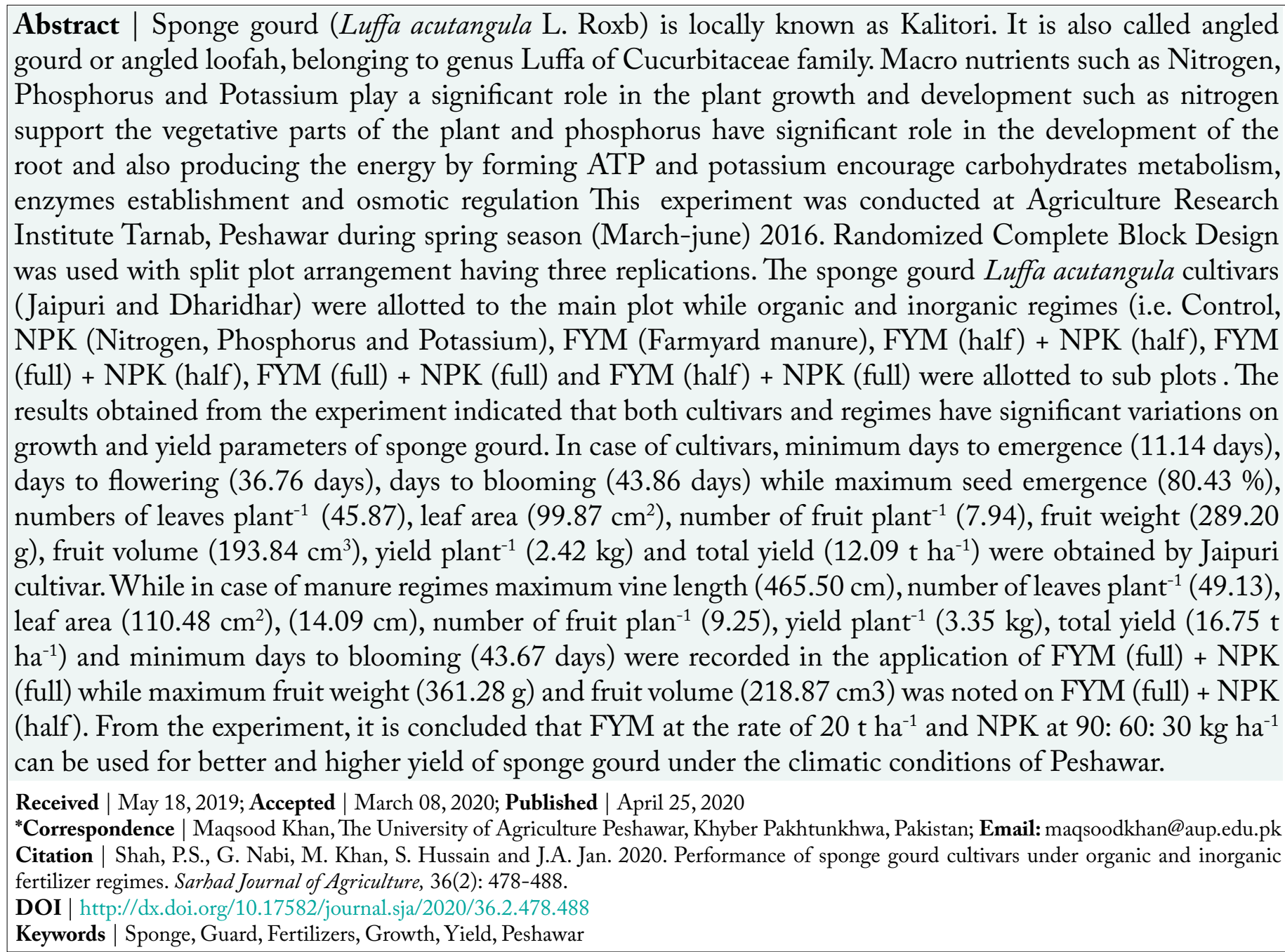

\section{Introduction}

Sponge gourd (Luffa acutangula L. Roxb) is Slocally known as Kalitori. It is also called angled gourd or angled loofah belonging to genus Luffa of Cucurbitaceae family (Zohura et al., 2013). Luffa is cross-pollinated crop having 26 chromosomes (Bal et al., 2004). It is a tropical and subtropical vine vegetable and is originated from America (Mazali and Alves, 2005). Sponge gourd is mainly composed of lignin, cellulose and hemicelluloses (Rowell et al., 2002). It is a nutrition powerhouse, an ideal weight loss food 
and strengthens immune system. The fruit contains protein $(0.5 \%)$, carbohydrate $(3 \%)$ and vitamin $\mathrm{C}$ (18 $\mathrm{mg}$ per $100 \mathrm{~g}$ ) of edible portion (Zohura et al., 2013). Oboh and Aluyor (2009) concluded that the importance of luffa increase in many fields such as medicine, environmental engineering, agriculture, biotechnology and also for food and industrial purposes (i.e., cleaning of utensils, absorber shocks, absorb sound, packing of materials, washroom sponge, use in factories as a filters, crafts making, chemical extractions and bio diesel) throughout the world. It has been reported from the latest studies that the profitable agriculture is improved due to the improving of economic importance of the Asia.

Sponge gourd grows well in soils having $\mathrm{pH}$ value around 6 to 6.8. Maximum rates of $\mathrm{K}$ and $\mathrm{P}$ is suggested for the growth of sponge gourd. Sponge gourd can grow in many soil types but for early and good crop establishment we need well drained sandy loams (Bal et al., 2004). Sponge can grow easily on the ground but for best production and good quality fruit you should grow them in trilling system. It can adopted to different climatic and soil conditions, however, excess rainfall during fruiting period and flowering can cause harm to the yield (Bal et al., 2004).

Macro nutrients such as Nitrogen, Phosphorus and Potassium play a significant role in the plant growth and development such as nitrogen support the vegetative parts of the plant and phosphorus have significant role in the development of the root and also producing the energy by forming ATP and potassium encourage carbohydrates metabolism, enzymes establishment and osmotic regulation (Shaheen et al., 2007). However, the large quantities of inorganic fertilizers are provided to vegetables in order to get higher yield and maximum income (Stewart et al., 2005). But the application of inorganic fertilizer alone may cause human health problems and also pollute the environment (Arisha and Bardisi, 1999). Therefore, the application of organic manure is also important as alternate source or with chemical fertilizers. When organic matters combined with mineral fertilizers and add to the soil it improves the plant quality and also improve soil fertility and should be used in any agricultural production (Kameswari et al., 2011). So to prolong soil health and gentle environment, reasonable appliance of organic and inorganic fertilizers is necessary. Therefore, inorganic fertilizer should be used along with organic fertilizers for vegetable production and may increase crop yield with minimum uses of chemical fertilizer. A lot of research work has been done on the utilization of industrial fertilizers in ridge gourd to enhance the production and productivity of the crop (Kameswari et al., 2011). In creeper crops like ridge gourd the incorporation of organic and inorganic fertilizers, present good possibility to raise the yield and productivity of the crop (Kameswari et al., 2011). Therefore, an attempt was made to study the performance of sponge gourd varieties under organic and inorganic regimes.

\section{Materials and Methods}

This experiment was conducted at the Agriculture Research Institute Tarnab, Peshawar during 2016. Two factors i.e. Cultivars (Jaipuri and Dharidhar) and fertilizers $\left(\mathrm{T}_{1}=\right.$ Control, $\mathrm{T}_{2}=$ NPK (90:60: 30 $\left.\mathrm{kg} \mathrm{ha}{ }^{-1}\right), \mathrm{T}_{3}=$ FYM $\left(20 \mathrm{tha}^{-1}\right), \mathrm{T}_{4}=$ FYM $\left(20 \mathrm{t} \mathrm{ha}^{-1}\right)$ + NPK (90: 60: $\left.30 \mathrm{~kg} \mathrm{ha}{ }^{-1}\right), \mathrm{T}_{5}=$ FYM $\left(10 \mathrm{t} \mathrm{ha}^{-1}\right)+$ NPK (45: 30: $15 \mathrm{~kg} \mathrm{ha}), \mathrm{T}_{6}=$ FYM $\left(20 \mathrm{tha}^{-1}\right)+\mathrm{NPK}$ (45: 30: 15) and $\mathrm{T}_{7}=\mathrm{FYM}\left(10 \mathrm{t} \mathrm{ha}^{-1}\right)+\mathrm{NPK}(90: 60$ : $30 \mathrm{~kg} \mathrm{ha}^{-1}$ ) were used. This experiment was arranged using Randomized Complete Block Design (RCBD) with split plot arrangement. Cultivars were assigned to main plots while fertilizer was assigned to subplots. Fertilizers were applied according to the treatments before planting. Then seeds were directly sown in the treatments and data for different parameters were recorded.

\section{Studied parameters}

Following are the parameters which were studied during the experiment.

Days to emergence were counted from the date of sowing to the $50 \%$ emergence for each sub plot and their average was calculated. Data for seedlings emergence percentage were also collected and average was calculated for analysis. Seed emergence was calculated by using the following formula.

$$
\text { Seedling Emergence (\%) }=\frac{\text { No of seedlings Emerged }}{\text { Total No of seeds sown }} \times 100
$$

For vine length randomly four plants were taken and their vine length was measured from tip to ground level at the end of the experiment by using measuring tape and their mean vine was calculated. Similarly, for number of leaves vine ${ }^{-1}$ randomly four vines were selected and their leaves were counted and their average was calculated for further analysis. For 
leaf area determination, randomly four leaves were selected from every plant and their leaf area was calculated with the help of leaf area machine and then their average was calculated for further analysis. For Days to first flower, number of days from sowing to first flower was counted for every sub plot and the average data were calculated for further analysis. In case of Days to bloom, the data regarding days to bloom were recorded by counting the number of days from sowing to $50 \%$ plants start flowering, and then average was calculated for further analysis. Similarly, for number of fruit plant ${ }^{-1}$ the total numbers of fruits per plant for four randomly selected plants at each sub plot were recorded at the end of harvest and average number of fruits per plant was calculated for further analysis. For Fruit weight (g), the weight of four randomly selected fruits per plot was recorded and then the average weight of fruit was calculated for further analysis. Fruit volume was noted by using water displacement method and then the average was calculated for further analysis. The data regarding yield plant ${ }^{-1}$ was recorded by weighing the total yield plot $^{-1}$ divided by total number of plants plot $^{-1}$, and then average was calculated for further statistical analysis. The yield in tons per hectare was calculated by using the following formula:

Yield in tons per hectare $=\frac{\text { Yield per plot in }(\mathrm{kg}) \times 10000 \mathrm{~m}^{2}}{\text { Area of the plot } \mathrm{m}^{2} \times 1000 \mathrm{~kg}}$

\section{Statistical analysis}

The collected data were statistically analyzed using Statistix software (version 8.1) by Jandel Scientific (1991) and means were compared by using least significance difference (LSD) test at 5\% level of significance.

\section{Results and Discussion}

Following parameters were studied during the experiments. Most of these were significantly affected by the treatments.

\section{Days to seedlings emergence}

Emergence of seedling is one of the important factors under consideration especially in the production of vegetables. Statistical analysis in our results shows that days to emergence was significantly affected by sponge gourd cultivars but it was found nonsignificant in fertilizer combination. Similarly, the interaction among cultivars and fertilizer combination was also non-significant. In sponge gourd cultivars, Jaipuri took less days (11.14 days) to germinate, while the cultivar Dharidhar took more days (14.43 days) to emerge. The difference among the time of germination of both the cultivars may be due to their genetic makeup. Some cultivars are early which complete their life cycle quickly (Raja et al., 2007). The other reason was Jaipuri may have thin seed coat due to which it absorbed moisture quickly as compared to cultivar Dharidhar (Grange et al., 2003). The plant does not need any food or nutrients for few days because there is enough food and all other things stored in the cotyledons which is necessary for seed germination (Fenner and Thompson, 2005).

\section{Seedling emergence (\%)}

Viability of seed is very important. Total production is positively correlated with number of viable seed produced by the plants. Data regarding seedling emergence percentage of sponge gourd is presented in Table 1 . The analysis of variance showed that seedlings emergence percentage was significantly affected by sponge gourd cultivars while it was nonsignificantly affected by fertilizers combination and their interaction was also found non-significant. The cultivar Jaipuri had greater seedlings emergence ( 88.43 \%) as compared to cultivar Dharidhar (66.67\%). The Jaipuri cultivar had greater seedlings emergence percentage because of the genetic combination. Some other factors may also be responsible for good emergence percentage which may be seed purity, climatic condition, thin seed coat, good moisture availability and favorable soil conditions (Lingaiah et al., 1993).

\section{Vine length $(\mathrm{cm})$}

Data regarding vine length $(\mathrm{cm})$ of sponge gourd cultivars are tabulated in Table 1 . Statistical analysis shows that there is a significant effect of fertilizer combination on vine length while the sponge gourd cultivars and the interaction of the treatments were found non-significant. In fertilizer combination maximum vine length $(465.50 \mathrm{~cm})$ was obtained on NPK (full) + FYM (full). While, minimum vine length $(349.67 \mathrm{~cm})$ was noted in control plots. Maximum vine length was obtained on FYM (full) + NPK (full). Because both the organic and inorganic fertilizers are the main sources of all the nutrients required by plants for their proper growth and development. Organic manure contains many important plant nutrients both micro and macro. 
Apart from this they also encourage aggregation of fine soil particles, improve soil structure and also important for soil microorganisms which increase soil physical and chemical properties due to which the performance of crop also improved (Basso and Ritchie, 2005). Likewise, inorganic fertilizes i.e. NPK are also important for plant growth and development and their deficiency cause several losses such as yield (Jones, 1983).According to Sareedhar et al. (2006) the maximum vine length, number of leaves and length of Gherkin was recorded in plots having recommended dose of NPK alongside organic manure. Sureshkumar and Karuppaiah (2008) reported that maximum vine length of bitter gourd was recorded with the application of NPK and organic manure.

\section{Number of leaves plant $t^{-1}$}

Number of leaves are important for the growth and production of any crop plant. Data regarding number of leaves of sponge gourd cultivars under organic and inorganic regimes are shown in Table 1. Analysis shows that number of leaves vine ${ }^{-1}$ of sponge gourd was significantly affected by cultivars and fertilizer combination while the interaction of the treatments had no significant variations. Cultivar Jaipuri had maximum numbers of leaves vine ${ }^{-1}(45.87)$ as compare to Dharidhar which have less numbers ofleaves (40.60). In case of fertilizer combination maximum number of leaves vine ${ }^{-1}$ (49.13) were recorded in FYM (full) + NPK (full). However, minimum numbers of leaves vine $^{-1}(35.25)$ were recorded in control. In cultivars the less number of leaves plant ${ }^{-1}$ were recorded on cultivar Jaipuri which may be due to genetic variability, good soil adoptive condition, moisture uptake strategy availability and favorable environmental condition (Laxman, 2012). In fertilizer combination maximum number of was recorded on FYM (full) + NPK (full). The organic manure are important for improving physical and chemical condition of the soil such as soil aeration, water holding capacity etc. and the use of inorganic fertilizers is essential for good growth and development of the plant (Kameswari et al., 2011). Hammad et al. (2011) reported that maximum number of leaves and tillers of wheat was recorded with the application of NPK and organic manure. Cheema et al. (2010) concluded that the vegetative growth of spring maize was significantly increased with the application of Urea and organic fertilizers. Das et al. (2015) noted maximum numbers of leaves in bottle gourd with the application of NPK and farmyard manure.
Leaf area $\left(\mathrm{cm}^{2}\right)$

Mean data on leaf area $\left(\mathrm{cm}^{2}\right)$ of sponge gourd cultivars under organic and inorganic regimes are shown in Table 1 . Which show significant variation among cultivars and nutrient applications. in case of interaction between cultivars and fertilizer combination the greater leaf area $\left(112.24 \mathrm{~cm}^{2}\right)$ was recorded on cultivar Jaipuri grown on FYM (full) + NPK (full) while the lower leaf area $\left(70.60 \mathrm{~cm}^{2}\right)$ was recorded on cultivar Dharidhar grown on Control. In cultivars the Jaipuri cultivar have large leaf area $\left(99.87 \mathrm{~cm}^{2}\right)$ as compared to Dharidhar $\left(90.56 \mathrm{~cm}^{2}\right)$. In case of fertilizers maximum leaf area (110.48 $\mathrm{cm}^{2}$ ) was noted in the plot treated with FYM (full) + NPK (full). While minimum leaf area $\left(77.22 \mathrm{~cm}^{2}\right)$ was determined in NPK which was significantly at par with control. Similarly, in cultivars the large leaf area was recorded on cultivar Dharidhar due to its genetic flexibility and some other factors such as good moisture availability, good environmental factors (Choudry and Sharma, 2002). Maximum leaf area was recorded on FYM (full) + NPK (full) because the organic manure has residual effect due to which it act as store house of most macro and micro nutrients that helps in increasing the area of the leaves (Gulshan et al., 2013). Likewise, with the application of macro nutrients such as NPK also increase the vegetative and reproductive stages of the plant (Ali et al., 2003). NPK plays an ultimate role in the metabolism of the plant due to which plants lead to the development of more number and maximum area of the leaves (Din et al., 2005). The leaf area of sorghum was large with the application of inorganic fertilizer (NPK) combine with organic fertilizer (Ahamd, 2007). Our results are in conformity with the results of Kameswari et al. (2011) who reported that with the addition of organic manure with inorganic fertilizers significantly increased the leaf area of the ridge gourd.

\section{Days to flowering}

Early flowering leads to early fruit set which is desirable for early marketing. Data on days to flowering of sponge gourd cultivars under organic and inorganic regimes are presented in Table 1 . Which revealed that it is significantly affected by sponge gourd cultivars and fertilizer combination while the interactions of the treatments were found non-significant. Minimum days (36.76 days) to flowering was noted in Jaipuri cultivar as compared to Dharidhar which takes (38.19 days). In fertilizer combination early flowering (37.00 days) was recorded in FYM (half) + NPK (half) 
which was statistically similar to all treatments of fertilizers except control (38.67 days). In mean table the fewer days to flowering was recorded on cultivar Jaipuri which was due to genetic variability as seen in this experiment and early emergence of the cultivar (Sanhi et al., 1987). In fertilizer combination the FYM (full) + NPK (full) took less days to emergence because the application of organic manure combined with inorganic fertilizer improved the vegetative growth of the crop (Huang and Lin, 2001). It has reported that the rate of released nutrients may not always complete the requirement of the plant but the combined application of organic and inorganic fertilizers can overcome this deficiency with the result of which plant take nutrients on time and increase their growth and development (Zhang and Fang, 2007). The results of Ehigiator (1988) showed that the combine application of chemical fertilizer and organic fertilizers results early emergence, early flowering and increase vegetative growth of the vegetables crops as a result of this plant yield and fruit yield increased. Ende and Talor (1996) concluded that the addition sheep manure with urea significantly influence the seedling growth and leaf nutrients composition of peach seedlings.

\section{Days to blooming}

Data regarding days to blooming of sponge gourd cultivars under organic and inorganic regimes are presented in Table 2. Mean data shows that Jaipuri cultivar took less days (43.86 days) to bloom as compared to Dharidhar (46.29 days). In fertilizer combination, less days to blooming (43.67 days) was recorded in FYM (full) + NPK (full). While maximum days to bloom (47.33 days) were recorded on control which was significantly at par with NPK and FYM.

In cultivars, Jaipuri took less days to blooming because of genetic flexibility and good environmental adoption strategy, good moisture availability and also early germination of the cultivar (Raja et al., 2007). While in fertilizer application FYM (full) + NPK (full) took minimum days to blooming because use of organic fertilizer such as farmyard manure increase soil structure, aeration and slow release of nutrients, as a result of which good development of root occur which lead to better growth and development (E1Magd et al., 2005). Moreover, Organic fertilizers play important role in plant growth due to presence of all macro and micro nutrients during mineralization and enhance physical and physiological properties of soils (Togun and Akanbi, 2003). The balance use of organic fertilizer and inorganic fertilizer has recommended for nutrition of long term cropping. Our results are in confirmity with the results of Rehman et al. (1998) who reported that the vegetative growth of berry was maximum with the integrated application of inorganic and organic fertilizers. Jose et al. (1988) found that the combine use of poultry manure and urea increase the germination, flowering and other vegetative and yield attributes of eggplant.

\section{Number of fruits plant ${ }^{-1}$}

Increase in number of fruits per plant is desirable which improve production. Table 2 shows number of fruit plant ${ }^{-1}$ of sponge gourd cultivars in response to organic and inorganic regimes. Statistical analysis shows the number of fruits plant ${ }^{-1}$ of sponge gourd was significantly affected by sponge gourd cultivars and fertilizers combination while the interaction of the treatments was found non-significant. In cultivars the Jaipuri cultivar gave maximum (7.94) number of fruits plant $^{-1}$ as compared with cultivar Dharidhar (7.27). In fertilizer combination the maximum number (9.25) of fruit plant $^{-1}$ was determined on FYM (full) + NPK (full) while the minimum number (5.50) of fruits plant ${ }^{-1}$ was noted on control. The number of fruits was significantly at par with NPK, FYM and FYM (half) + NPK (half). In cultivars maximum number of fruit plant ${ }^{-1}$ was noted on cultivar Jaipuri due to several factors like genetic flexibility, maximum leaf length and leaf width due to which maximum chlorophyll was occurred and results maximum number of fruits plant ${ }^{-1}$ (Raja et al., 2007). While in case of fertilizers maximum number of fruit was recorded in FYM (full) + NPK (full) because the organic manures increased organic content in the soil due to which soil water holding capacity and water stable aggregation increased and thus increased all the growth and yield parameters of the plant (Bwenya and Terokun, 2001). Similarly, chemical fertilizers maintain and improve crop yield and quality (Haynes and Naidu, 1998). Anitha et al. (2003) concluded that the maximum yield of pickling melon was recorded with the addition of 10 tons vermicompost and recommended dose of NPK. Similarly, Anjanappa et al. (2012) reported that improved yield parameters of cucumber such as number of fruits vine ${ }^{-1}$ and maximum fruit weight was noted with the application of farmyard manure, Phospho bacteria and NPK. 
Table 1: Days to emergence, emergence \%, vine length, number of leaves, leaf area and days to flowering of two cultivars grown under organic and inorganic regimes.

$\begin{array}{lllllll}\begin{array}{l}\text { Organic and inorganic } \\ \text { regimes }\end{array} & \begin{array}{l}\text { Days to } \\ \text { emergence }\end{array} & \text { Emergence \% } & \text { Vine length }(\mathbf{c m}) & \begin{array}{l}\text { No. of leaves Leaf area } \\ \left(\mathbf{c m}^{2}\right)\end{array} & \begin{array}{l}\text { days to } \\ \text { flowering }\end{array} \\ \text { Control } & 13 & 73.67 & 349.67 \mathrm{c} & 35.25 \mathrm{c} & 77.22 \mathrm{e} & 38.67 \mathrm{a} \\ \text { NPK } & 12.83 & 73.17 & 408.13 \mathrm{~b} & 43.17 \mathrm{~b} & 88.63 \mathrm{~d} & 37.33 \mathrm{~b} \\ \text { FYM } & 12.83 & 73.83 & 397.25 \mathrm{~b} & 43.54 \mathrm{~b} & 85.19 \mathrm{~d} & 37.50 \mathrm{~b} \\ \text { FYM (half) + NPK (half) } & 12 & 73.17 & 388.63 \mathrm{bc} & 43.04 \mathrm{~b} & 98.19 \mathrm{c} & 37.00 \mathrm{~b} \\ \text { FYM (full) + NPK (half) } & 13.17 & 72.67 & 456.25 \mathrm{a} & 45.29 \mathrm{ab} & 104.98 \mathrm{~b} & 37.33 \mathrm{~b} \\ \text { FYM (full) + NPK (full) } & 12.5 & 74.83 & 465.50 \mathrm{a} & 49.13 \mathrm{a} & 110.48 \mathrm{a} & 37.33 \mathrm{~b} \\ \text { FYM (half) + NPK (full) } & 13.17 & 73.5 & 398.50 \mathrm{~b} & 43.21 \mathrm{~b} & 101.81 \mathrm{~b} & 37.17 \mathrm{~b} \\ \text { LSD 5\% } & \mathrm{ns} & \mathrm{ns} & 43.86 & 3.8 & 3.51 & 0.84 \\ \text { Cultivars } & & & & & & \\ \text { Jaipuri } & 11.14 \mathrm{~b} & 80.43 \mathrm{a} & 409.05 & 45.87 \mathrm{a} & 99.87 \mathrm{a} & 36.76 \mathrm{~b} \\ \text { Dharidhar } & 14.43 \mathrm{a} & 66.67 \mathrm{~b} & 409.21 & 40.60 \mathrm{~b} & 90.56 \mathrm{~b} & 38.19 \mathrm{a} \\ \text { LSD 5\% } & 0.35 & 1.47 & \mathrm{~ns} & 1.1 & 1.16 & 0.71\end{array}$

Table 2: Days to blooming, number of fruits, fruit weight, fruit volume, yield per plant and total yield of two cultivars grown under organic and inorganic regimes.

\begin{tabular}{lllllll} 
Organic and inorganic regimes & \multicolumn{2}{l}{ days to blooming no. of fruits } & fruit wt (gm) & fruit volume & $\begin{array}{l}\text { yield pr plant } \\
\text { (ug) }\end{array}$ & $\begin{array}{l}\text { perha yield } \\
\text { (tha-1) }\end{array}$ \\
& & & & & & \\
Control & $47.33 \mathrm{a}$ & $5.50 \mathrm{~d}$ & $208.39 \mathrm{e}$ & $163.62 \mathrm{f}$ & $1.51 \mathrm{~d}$ & $7.54 \mathrm{~d}$ \\
NPK & $45.00 \mathrm{c}$ & $6.79 \mathrm{c}$ & $246.93 \mathrm{~cd}$ & $175.85 \mathrm{e}$ & $1.67 \mathrm{~d}$ & $8.37 \mathrm{~d}$ \\
FYM & $46.00 \mathrm{~b}$ & $7.46 \mathrm{bc}$ & $228.87 \mathrm{~d}$ & $184.62 \mathrm{~d}$ & $1.72 \mathrm{~cd}$ & $8.58 \mathrm{~cd}$ \\
FYM (half) + NPK (half) & $44.17 \mathrm{~cd}$ & $7.54 \mathrm{bc}$ & $318.42 \mathrm{~b}$ & $201.50 \mathrm{~b}$ & $2.02 \mathrm{c}$ & $10.12 \mathrm{c}$ \\
FYM (full) + NPK (half) & $44.67 \mathrm{c}$ & $8.38 \mathrm{~b}$ & $361.28 \mathrm{a}$ & $218.87 \mathrm{a}$ & $2.68 \mathrm{~b}$ & $13.40 \mathrm{~b}$ \\
FYM (full) + NPK (full) & $43.67 \mathrm{~d}$ & $9.25 \mathrm{a}$ & $268.92 \mathrm{c}$ & $193.15 \mathrm{c}$ & $3.35 \mathrm{a}$ & $16.75 \mathrm{a}$ \\
FYM (half) + NPK (full) & $44.67 \mathrm{c}$ & $8.33 \mathrm{~b}$ & $319.82 \mathrm{~b}$ & $202.10 \mathrm{~b}$ & $2.66 \mathrm{~b}$ & $13.32 \mathrm{~b}$ \\
LSD 5\% & 0.96 & 0.89 & 24.05 & 3.51 & 0.33 & 1.66 \\
Cultivar & & & & & & \\
Jaipuri & $7.94 \mathrm{a}$ & $289.20 \mathrm{a}$ & $193.84 \mathrm{a}$ & $193.84 \mathrm{a}$ & $2.42 \mathrm{a}$ & $12.09 \mathrm{a}$ \\
Dharidhar & $7.27 \mathrm{~b}$ & $268.69 \mathrm{~b}$ & $188.93 \mathrm{~b}$ & $188.93 \mathrm{~b}$ & $2.04 \mathrm{~b}$ & $10.21 \mathrm{~b}$ \\
LSD 5\% & 0.54 & 19.3 & 2.65 & 2.65 & 0.19 & 0.98
\end{tabular}

\section{Fruit weight (g)}

In sponge gourd cultivars, greater fruit weight $(289.20 \mathrm{~g})$ was noted in cultivar Jaipuri while cultivar Dharidhar have less $(268.69 \mathrm{~g})$ fruit weight. In fertilizer combination maximum fruit weight (361.28 g) was recorded in FYM (full) + NPK (half) while control have less (208.39 g) fruit weight. Mean table shows that the cultivar Jaipuri have greater fruit weight which was due to maximum leaf length, maximum leaf width which results maximum photosynthesis in the leaf and produced heavy and maximum fruits by the plants. The other factors may be genetic variability favorable environmental conditions and good moisture availability (Rabbani et al., 2012). The combination of FYM (full) + NPK (half) gave maximum fruit weight because the impact of organic and inorganic fertilizers is necessary for improving soil fertility and sustainable agriculture (Mukesh et al., 2017). It is necessary to make cautious use of organic and inorganic fertilizer for getting better crops and also sustaining soil fertility. For sustaining soil fertility and good crop productivity, the integrated nutrient management (INM) is the best technique to use (Choudhary, 2006). Integrated nutrient management is also necessary for enhancing the availability of macro and micro nutrients thus for improving the soil physical, chemical and biological properties of the soil and getting the economic and effectiveness in fertilizer use (Eifediyi and Remison, 2010).Our results are similar with the results of June 2020 | Volume 36 | Issue 2 | Page 483 
Tomar et al. (1998) who reported that the significant increase was occur in yield and yield attributes with the application of organic and inorganic fertilizers in carrot and brinjal.

\section{Fruit volume $\left(\mathrm{cm}^{3}\right)$}

Statistical analysis shows maximum fruit volume $\left(222.50 \mathrm{~cm}^{3}\right)$ was recorded in Jaipuri grown on FYM (full) + NPK (half) while minimum fruit volume $\left(159.87 \mathrm{~cm}^{3}\right)$ was noted on Dharidhar grown on Control considering the interactive effects. However, maximum $\left(193.84 \mathrm{~cm}^{3}\right)$ fruit volume was obtained in cultivar Jaipuri while minimum $\left(188.93 \mathrm{~cm}^{3}\right)$ was obtained in Dharidar. In fertilizer combination, maximum $\left(218.87 \mathrm{~cm}^{3}\right)$ fruit volume was recorded on FYM (full) + NPK (half). While minimum (163.62 $\mathrm{cm}^{3}$ ) fruit volume was noted on Control. In case of cultivars, the maximum fruit volume was noted in cultivar Jaipuri because of maximum fruit length maximum fruit weight (Laxman, 2012). In regimes the maximum fruit volume was recorded on FYM (full) + NPK (half) because the addition of organic manure with inorganic fertilizers can play a significant function in vegetables farming. Integrated nutrient use has a huge impact on vegetables production. This practice enhanced the soil productivity under huge exhaustive cropping system (Singh and Yadav, 1992). However, the addition of natural fertilizer as a source of a quantity of necessary nutrients which has positive effect on soil chemical and physical properties which eventually will improve the productivity. Subbiah et al. (1985) recorded maximum yield of eggplant and tomato with the integrated use of FYM and NPK. Our results also confirmed with the results of Shelke et al. (1999) who found that the maximum fruit volume was obtained with the addition of urea and poultry manure. Jablonska (1990) and Hosmani (1993) also found that combined application of organic and fertilizers results maximum yield of tomato, eggplant, pepper and chilli.

\section{Yield plant ${ }^{-1}(\mathrm{~kg})$}

Mean data shows that Jaipuri cultivar produced maximum $(2.42 \mathrm{~kg})$ yield plant $^{-1}$ as compared to Dharidhar $(2.04 \mathrm{~kg})$. In case of fertilizers, maximum yield plant ${ }^{-1}(3.35 \mathrm{~kg})$ was recorded in FYM (full) + NPK (full) and minimum yield plant ${ }^{-1}(1.51 \mathrm{~kg})$ was recorded in control. The difference between NPK, FYM and control was statistically at par. The cultivar Jaipuri gave maximum yield plant ${ }^{-1}$ due to many reasons like maximum number of fruits plant ${ }^{-1}$, maximum fruit weight etc. which are responsible for maximum yield plant $^{-1}$ as well as some genetic and environmental factors (Lingaiah et al., 1993). Several other factors such good performance of the cultivar because of the favorable climate of Peshawar for cultivar and good water and nutrients utilization of the cultivar etc. The maximum yield plant $^{-1}$ was obtained by FYM (full) + NPK (full) because with the application of FYM and NPK the luxury supply of nitrogen, phosphorus, potassium and other micro nutrients are available to the plants. Thus, it absorbs various physiological and metabolic processes particularly protein metabolism (Latha et al., 2014). The availability of all the nutrients to the plant, increase yield and yield par parameters. Organic fertilizers are microbial in source and are helpful in increasing yield, quality and production of crop when they are used in combination of inorganic fertilizers in a balanced proportion (Kumar et al., 2012). The results of our experiment are corroborated with the results of Mulani et al. (2007). They concluded that with the interaction of organic and inorganic fertilizers significantly improved number of fruits, fruit length, fruit girth and thus also increase yield of the bitter gourd.

\section{Total yield ( $\left.\mathrm{h} \mathrm{a}^{-1}\right)$}

According to the statistical analysis total yield was significantly affected by cultivars in response to organic and inorganic regimes. In cultivars Jaipuri produced maximum $\left(12.09 \mathrm{t} \mathrm{ha}^{-1}\right)$ total yield of sponge gourd as compared to Dharidhar $\left(10.21 \mathrm{t} \mathrm{ha}^{-1}\right)$. While in case of fertilizers, maximum total yield $\left(16.75 \mathrm{t} \mathrm{ha}^{-1}\right)$ of sponge gourd was determined in FYM (full) + NPK (full) while minimum total yield $\left(7.54 \mathrm{t} \mathrm{ha}^{-1}\right)$ was recorded in control which was statistically similar with NPK and FYM. The cultivar Jaipuri gave maximum total yield which was due to many reasons such as genetic makeup, favorable environmental condition, maximum number of leaves, maximum leaf area of the cultivar due to which maximum photosynthesis occur in the plant and produced maximum fruit plant ${ }^{-1}$, maximum fruit weight and maximum yield plant ${ }^{-1}$. And as a result of all these maximum total yields were obtained (Raja et al., 2007). The application of FYM (full) + NPK (full) produced maximum yield of sponge gourd because the inorganic source of nutrients with the addition of organic source such farmyard manure, poultry manure or vermicompost increased plant growth favorably with the synthesis of more carbohydrates. Under these circumstances, flow 
of assimilates to sink was maximum and maybe they caused higher fruit length, fruit weight and maximum yield of the crop (Hilli et al., 2009). In addition to this yield is the demonstration of physiological, morphological, biochemical and growth parameters and known as the results from the capturing and exchange of solar energy efficiency. Yield of a plant is polygenic in nature and affected on many internal and external factors throughout the growth period (Kameswari and Narayanamma, 2009). Similar results were noted by Saeed et al. (2002) in sunflower who reported that organic manure with combination of inorganic fertilizers significantly increase quality and yield of sunflower.

\section{Conclusions and Recommendations}

From the results of the experiment it is concluded that sponge guard cultivars perform well under the application of fertilizers. But overall Jaipuri cultivar perform better than the other one. FYM at the rate of $20 \mathrm{t} \mathrm{ha}^{-1}$ and NPK at 90:60: $30 \mathrm{~kg} \mathrm{ha}^{-1}$ can be applied to Jaipuri cultivar for higher yield of sponge gourd under the climatic conditions of Peshawar.

\section{Novelty Statement}

This research was conducted to compare the performance of sponge guard under organic and inor-ganic fertilizers. Findings of this experiment will encourage the farmer to use organic sources of fertilizers with combination of NPK. This will help in the establishment of organic farming system.

\section{Author's Contribution}

Peer Sikandar Shah: Designed and Perform the experiment.

Ghulam Nabi: Supervised the experiment, pro-vided guidance and valuable suggestions.

Maqsood Khan: Helped in designing experiment, data collection, analysis and paper writing.

Saddam Hussain: Helped in data collection, analysis and constructive discussion.

Jawad Ali Jan: Helped in data collection, analysis and constructive discussion.

\section{Conflict of interest}

The author declare no conflict of interest.

\section{References}

Ahmad, B., 2007. Effect of different levels of nitrogen and seedling density on growth, yield and quality of Sorghum. M.Sc. (Hones) Agric. thesis., Dept. Agron., Univ. Agric., Faisalabad.

Ali, N., M. Rehman and S.A. Hussain. 2003. Response of Momordica charantia L. (Bitter gourd) cultivars to nitrogen levels. Sarhad J. Agric., 32(5): 585-589.

Anitha, S., M. Jyotni, M.C.N. Kuttyand and L.B. Nair. 2003. Evaluation of various organic manure as components in the integrated nutrient management of oriental pickling melon (Cucumis melon var. conomon). Prog. Hortic. 35: 155-157.

Anjanappa, M., B.S. Kumara and K.M. Indiresh. 2012. Growth, yield and quality attributes of cucumber (cv. Hassan Local) as influenced by integrated nutrient management grown under protected condition. Mysore J. Agric. Sci. 46(1): 32-37.

Anjanappa, M., J. Venkatesh and B.S. Kumara. 2012. Influence of organic, inorganic and bio fertilizers on flowering, yield and yield attributes of cucumber (cv. Hassan Local) in open field condition. Karnataka J. Agric. Sci. 25(4): 493497.

Arisha, H.M. and A. Bradisi. 1999. Effect of mineral fertilizers and organic fertilizers on growth, yield and quality of potato under sandy soil conditions. Zagazig J. Agric. Res. 26: 391405.

Bal, K.J.,B.K.C.Hari, K.T. Radha, G. Madhusudan, R.S. Bhuwon and P.U. Madhusudan. 2004. Descriptors for sponge gourd (Luffa cylindrical L.). NARC, LIBIRD and IPGRI.

Basso, B. and J.T. Ritchie. 2005. Impact of compost manure and inorganic fertilizer on nitrate leaching and yield for a 6 year maize alfalfa rotation in Michigan. Agric. Ecosys. Environ. 108: 309-341. https://doi.org/10.1016/j. agee.2005.01.011

Bwenya, S. and O.A. Terokun. 2001. Effect of cassia spectabilis, cow dung and their combination on growth and grain yield of maize. Seventh Eastern and Southern Africa Regional Maize Conference, Nairobi, Kenya. $11^{\text {th }}-15^{\text {th }}$ February. pp. 361-406.

Cheema, M.A., W. Farhad, M.F. Saleem, H.Z. Khan, A.Munir, M.A. Wahid, F. Rasul and 
H.M. Hammad. 2010. Nitrogen management strategies for sustainable maize production. Crop Environ. 1(1): 49-52.

Choudhary, S. 2006. Effect of organic and inorganic sources of nutrients on growth, yield and quality of sprouting broccoli (Brassica oleracea. var. Plenck) cv. C.B.H-1. M.Sc thesis, submitted to Rajasthan Agricultural University, Bikaner, Campus-Jobner (Rajasthan).

Choudhry, D. and K.C. Sharma. 2002. Studies on variability, heritability, genetic advances and correlation in ridge gourd ( $\mathrm{Luffa}$ acutangula Roxb.). Hortic. J. 15(3): 53-58.

Das, R., A.R. Mandal, A. Priya, S.P. Das and J. Kabiraj. 2015. Evaluation of integrated nutrient management on the performance of bottle gourd. J. Appl. Nat. Sci. 7 (1): 18 - 25. https:// doi.org/10.31018/jans.v7i1.557

Din, M.A., T. Meryem, M. Azeem and H.M. Saeed. 2005. Effect of NPK on various growth and yield parameters of tomatoes. J. Agric. Bio. Sci. 42(6): 665 - 671.

Ehigiator, J.O., 1988. Farmyard manure: Need for its adoption as an alternative to mineral fertilizer use in Nigeria. Niger. J. Hortic. Sci. 3: 1-9.

Eifediyi, E.K. and S.U. Remison. 2010. Growth and yield of cucumber (Cucumis sativus) as influenced by farmyard manure and inorganic fertilizer. Science pub.net/report.

El-Magd, M., M. Hoda, A. Mohamed and Z.F. Fawzy. 2005. Relationship growth, yield of broccoli with increasing $\mathrm{N}, \mathrm{P}$ or $\mathrm{K}$ ratio in a mixture of NPK fertilizers (Brassico oleracea). Ann. Agric. Sci. Moshtohor. 43(2): 791-805.

Ende, D.B. and B.K. Talor. 1996. Responses of peach seedlings in sand culture to fractional combinations of nitrogen, phosphorus, potassium and sheep manure. Aust. J. Exp. Agric. 37: 234-236.

Fenner, M. and K. Thompson. 2005. The ecology of seeds. Cambridge. International standard book number (ISBN). 978-0521653-114.

Grange, S., D.L. Leskover, L.M. Pike and B.G. Cobb. 2003. Seed coat structure and oxygen enhanced environments affects germination of tropical watermelon. J. Am. Soc. Hortic. Sci. 128(2): 253-259. https://doi.org/10.21273/ JASHS.128.2.0253

Gulshan, A.B., H.M. Saeed, S. Javid, T. Meryam, M. Imran and M.A. Din. 2013. Effect of animal manure on the growth and development of okra (Abelmoschus esculentus L.). J. Agric. Biol. Sci. 8(3): 213-218.

Hammad, H.M., A. Khaliq, A. Ahmad, M. Aslam, A.H. Malik and W. Farhad. 2011. Influence of different organic manures on wheat productivity. Int. J. Agric. Biol. 4(13): 137-140.

Haynes, R.J. and R. Naidu. 1998. Influence of lime, fertilizer and manure applications on soil organic matter content and soil physical conditions. Nutr. Cycl. 51: 123-137.

Hilli, J.S., B.S. Vyakarnahal, D.P. Biradar and R. Hunje. 2009. Influence of method of trailing and fertilizer levels on seed yield of ridge gourd (Luffa acutangula L. Roxb). Karnataka J. Agric. Sci. 22(1): 47-52.

Hosmani, M.M., 1993. Chili crop (Capsicum annuum L.). $2^{\text {nd }}$ Edition. Mrs. S.M. Hosmani, Dharwad, Karnataka. Chilli Crop. Ed. 2. Univ. Agric. Sci., Dharwad, Karnataka. pp. 232.

Huang, S.N. and J.C. Lin. 2001. Current status of organic materials recycling in Southern Taiwan. Soil Fert. Exp. Bull., 3: 43-48.

Jablonska, C.R., 1990. Straw as an organic fertilizer in cultivation of vegetables. Part II. Effect of fertilization with straw on the growth of vegetable plants. Hortic. Abstr., 63: 244.

Jones, J.B., 1983. A guide for the hydroponic and soil-less culture grower. Timber Press, Beaverton, Oregon, pp. 124.

Jose, D., K.G. Shanmugavelu and S. Thamburaj. 1988. Studies on the efficiency of organic vs. inorganic form of nitrogen in brinjal. Indian J. Hortic., 45: 100-103.

Kameswari, P.L. and M. Narayanamma. 2011. Influence of integrated nutrient management in ridge gourd (Luffa acutangula L.). J. Res. Angrau. 39 (3):16-20.

Kameswari, P.L., M. Narayanamma, S.R. Ahmed and A. Chaturvedi.2011.Influence of integrated nutrient management in ridge gourd ( $L$ uffa acutangula L.). Vegetable Sci. 38(2): 209-211.

Kumar, V., V.K. Singh and R. Teena. 2012. Effect of integrated nutrient management on economics in bottle-gourd (Lagen ariasiceraria L.). Environ. Ecol. 30 (4A): 1410-1412.

Latha, P., S. Jeyaraman and R. Prabakaran. 2014. Effect of microbial and chemical fertilizer on egg-plant (Solanum melongena Linn.) C.var CO-2. Int. J. Pure Appl. Biol. Sci. 2(4): 119124. 
Laxman, B.D., 2012. Performance of bitter gourd (Momordica charantia L.) varieties and nature of cultivation with respect to growth, yield and quality. M.Sc (Hortic.) thesis. S.D. Agric. Univ., Sardar krushinagar.

Lingaiah, H.B., B.C. Uthaiah and P.S. Herle. 1993. Performance of bitter gourd cultivars in coastal Karnataka. Curr. Res. Univ. Agric. Sci. 22(1): 16.

Mazali,I.O.and O.L.Alves.2005.Morphosynthesis: High fidelity inorganic replica of the fibrous network of loofa sponge (Luffa cylindrica). An. Acad. Bras. Cien. 77(1): 25-31. https://doi. org/10.1590/S0001-37652005000100003

Mukesh, N., A.K. Soni and D.K. Sarolia. 2017. Effect of organic manures and different levels of NPK on growth and yield of bottle gourd. Int. J. Curr. Microbiol. App. Sci. 6(5): 1776-1780. https://doi.org/10.20546/ijcmas.2017.605.193

Mulani, T.G., A.M. Musmade, P.P. Kadu and K.K. Mang-ove. 2007. Effect of organic manures and bio-fertilizer on growth, yield and quality of bitter gourd (Memordica charantia L.) cv. Phule green gold. J. Soil Crops, 17: 258-261.

Oboh, O. and E.O. Aluyor. 2009. (Luffa cylindrical L.). An emerging cash crop. Afr. J. Agric. Res. 4(8): 684-688.

Rabbani, M.G., M.J. Naher and S. Hoque. 2012. Variability, character association and diversity analysis of ridge gourd (Luffa acutangula Roxb.) genotypes of Bengladesh. SAARC J. Agric. 10(2): 1-10. https://doi.org/10.3329/sja. v10i2.18319

Rahman, M.M., M.A.M. Sarker, A. Hasina and M.A. Kashem. 1998. Role of some indigenous substances as organic fertilizers on the growth and yield of brinjal plants. Bangladesh J. Sci. Indus. Res. 33(2): 275-281.

Raja, S., B.G. Bagle and D.G. Dhandar. 2007. Genetic variability studies in bitter gourd for zero irrigated condition of semi-arid ecosystem. Indian J. Hortic. 64(4): 425-429.

Rowell, R.M., S.H. James and S.R. Jeffrey. 2002. Characterization and factors effecting fiber properties, In Frollini E, Leao, AL, Mattoso LHC, (ed.), Natural polymers and agrofibers based composites. Embrapa Instrum. Acao Agropecuaria, san Carlos, Brazil. pp.115-134.

Saeed, N., M. Hussain and M. Saleem. 2002. Interactive effect of biological sources and organic amendments on the growth and yield attributes of sunflower (Helianthus annuus L.), Pak. J. Agric. Sci. 39(2): 135-136.

Sahni, G.P., R.K. Singh and B.C. Saha. 1987. Genotypic and phenotypic variability in ridge gourd. Indian J. Agric. Sci. 57(9): 666-668.

Sareedhar, P., A. Anburani and J. Samruban. 2006. Influence of integrated nutrient management on growth of gherkin (Cucumis sativus L.) cv. Ajex Hybrid. Veg. Sci. (33): 196-197.

Shaheen, A.M., M.M. Abdel-Mouty, A.H. Ali and F.A. Rizk. 2007. Natural and chemical phosphorus fertilizers as affected onion plant growth, bulbs yield and its some physical and chemical properties. Aust. J. Basic Appl. Sci. 1(4): 519 - 524.

Shelke, S.R., R.N. Adsule and V.M. Amrutsagar. 1999. Nitrogen management through organic and inorganic in Brinjal. J. Maharashtra Agric. Univ. 24 (3): 297-298.

Singh, G.B. and D.V. Yadav. 1992. Integrated plant nutrition system in sugarcane. Fert. News. 37: $15-22$.

Stewart, M.W., W.D. Dibb, E.A. Johnston and J.T. Smyth. 2005. The contribution of commercial fertilizer nutrients to food production. Agron. J., 97: 1-6. https://doi.org/10.2134/ agronj2005.0001

Subbiah, K., S. Sundararajan, S.Muthuswami and R. Perumal. 1985. Responses of tomato and brinjal to varying levels of FYM and macronutrients under different fertility status of soil. South Ind. Hortic. 33 (4): 198-205.

Sureshkumar, R. and P. Karuppaih. 2008. Effect of inte-grated nutrient management on growth and yield of bitter gourd (Momordica charantia L.) type Mithi-pagal. Plant Arch. (8): 867-868. Togun, A.O. and W.B. Akanbi. 2003. Comparative effectiveness of organic-based fertilizers to mineral fertilizers on tomato growth and fruit yield. Compost Sci. Util., 11: 337-342. https:// doi.org/10.1080/1065657X.2003.10702143

Tomar, V.K., R.K. Bhatnagar and R.H. Patta. 1998. Effect of vermicompost on production of brinjal and carrot. Bhartiya Krishi Anusandhan Patrika, 13: 153-156.

Zhang, M. and L. Fang. 2007. Effect of tillage, agronomy fertilizer and green manure cropping on soil quality at an abandoned brick making site. Soil Tillage Res. 93(3): 87-93. https://doi. org/10.1016/j.still.2006.03.016

Zohura, F.T., M.E. Haque, M.A. Islam, M. Khalekuzzaman and B. Sikdar. 2013. Establishment of efficient in vitro regeneration 
